\title{
Technical and Didactic Knowledge of the Moodle LMS in Higher Education. Beyond Functional Use
}

\author{
Julio Cabero-Almenara1* (1), Maria Luisa Arancibia² (1), Annachiara Del Prete ${ }^{3}$ (1) \\ 'Department of Educational Organization and Didactics, University of Seville, Spain \{cabero@us.es\} \\ ${ }^{2}$ Centre for Innovation in Education, Universidad Tecnológica de Chile INACAP, Chile \\ \{marancibiam@inacap.cl\} \\ ${ }^{3}$ Centre for Innovation in Education, Universidad Tecnológica de Chile INACAP, Chile \\ \{aadelprete@inacap.cl\}
}

Received on 30 May 2018; revised on 7 June 2018; accepted on 3 September 2018; published on 15 January 2019

DOI: $10.7821 /$ naer.2019.1.327

(cc) BY-NC-ND

\begin{abstract}
Higher education institutions at the international level have seen the need to adopt and integrate information and communication technologies to meet the opportunities and challenges of innovation in teaching and learning processes. This logic has led to the implementation of virtual learning environments called 'Learning Management Systems', the functionalities of which support flexible and active learning under a constructivist approach. This study measured didactic and technological use of Moodle and its implications in teaching from a quantitative approach by administering a questionnaire to a sample of 640 higher education teachers. Some guiding questions were as follows: Are teachers using the Moodle platform for didactic purposes? What strategies, resources and tools are teachers using, and what do they contribute to student-centred teaching? Are teaching strategies that are focused on collaboration, interaction and student autonomy promoted? The results coincide with those of other studies, confirming an instrumental and functional use of the platform, which is mainly being used as a repository for materials and information, while its pedagogical use remains limited. This is becoming a problem in higher education institutions, something that requires debate and reflection from a systemic perspective on the adoption and integration of technology in the classroom.
\end{abstract}

KEYWORDS: VIRTUAL TRAINING, MOODLE, E-LEARNING, TEACHER TRAINING.

\section{VIRTUAL TRAINING}

Virtual training is becoming one of the most used methods of training both in its full application of e-learning or mixed with face-to-face training and b-learning in higher education. However, it is increasingly reaching other education levels (Luo, Murray, \& Crompton, 2017) because of its potential to accommodate flexible, interactive, multimedia and decentralised teaching. Its technological base is supported by learning managers or 'Learning Management Systems' (LMS) (Pérez, Herrera Maldonado, \&

*To whom correspondence should be addressed:

Facultad de Ciencias de la Educación de la Universidad de Sevilla Departamento de Didáctica y Organización Educativa Universidad de Sevilla

c/ Pirotecnia s/n 41013, Sevilla, Spain
Mendoza, 2008; Rienties, Giesbers, Lygo-Baker, Serena, \& Rees, 2014), Moodle being one of the most used platforms internationally, and as noted by Kerimbayev, Kultan, Abdykarimova and Akramova (2017), it presents a number of advantages: it works without modifications in any operating system compatible with PHP. It works as a set of modules and allows you to add or remove elements flexibly at different stages.

On this platform, teachers and students show high levels of satisfaction and technological acceptance (Inzunza, Rocha, Márquez, \& Duk, 2014; Horvat, Dobrota, Krsmanovic, \& Cudanov, 2015; Schoonenboom, 2014), and teachers tend to perceive that its use improves educational practice and presents a wealth of advantages (Jenaro, Martín, Castaño, \& Flores, 2018; Kerimbayev, Kultan, Abdykarimova, \& Akramova, 2017; Ndlovu and Mostert, 2017). However, different research has been carried out that concludes that there is indeed greater use of LMS platforms but that there is no generalised evidence of a change in pedagogical practice (Brown, 2008; Browne, Jenkins, \& Walker, 2006; Kinchin, 2012), where teachers tend to use it more to transmit knowledge than to develop, invent and create knowledge (Fariña, González, \& Area, 2013). This is spurring debate in universities because they have invested economic and human resources into implementing LMS and educational practices have not changed.

Research has shown that many teachers only use a minimum of LMS's possibilities (Jenkins, Browne, Walker, \& Hewitt, 2010; Rienties \& Townsend, 2012). More clearly, the 'Study of Undergraduate Students and Information Technology 2017' ECAR report (Brooks \& Pomerantz, 2017) notes that $75 \%$ use institutional LMSs mainly for tasks related to uploading the course syllabus, publishing materials, delivering notes and requesting and collecting homework.

The reasons for this situation are varied, ranging from not really contemplating the critical variables to achieve quality virtual training, to the training that teachers receive. With regard to the first point, recently, Marciniak and Gairín (2017) conducted an analysis of different models to analyse quality in virtual education, which allowed them to create a model for the analysis of virtual training quality that is constructed around six large dimensions: 1) institutional context (analysis of training needs, infrastructure, human resources and financial situation); 2) students (characteristics of the recipients and factors that influence student satisfaction); 3) teachers (online teacher profiles, factors that influence their satisfaction and professional development); 4) technological infrastructure (from the pedagogical and techno- 
logical perspectives); 5) pedagogical aspects (training objectives, didactic materials and resources, learning activities, learning assessments, teaching strategies and tutoring); and 6) the life cycle of a virtual course/programme (design, development and evaluation/results). With regard to the second point, it is essential for technology integration in the classroom to involve teacher training to understand not only technological and instrumental technology but also what is beginning to be called pedagogical and content knowledge (Cabero, Roig, \& Mengual, 2017; Cejas, Navío, \& Barroso, 2016; Koehler \& Mishra, 2008).

To this end, on the one hand, it is necessary to rethink teacher-centred teaching approaches and direct them towards a student-centred approach (Silva, García, Guzmán, \& Chaparro, 2016); on the other hand, it is necessary to look for new ways and approaches to carry it out (Cabero \& Marín, 2014; Martínez \& Torres, 2017).

\subsection{Use of the Moodle platform to support the teaching-learning process: possibilities and barriers}

The use of the platforms under teaching assets is suitable for teachers and students to carry out collaborative activities and incorporate them successfully into the dynamics of the teachinglearning process (Coicaud, 2016; Silva, Fernández, \& Astudillo, 2014; Silva et al., 2016). The Moodle platform, from a functional perspective, has easily configurable characteristics, which allows the creation of student assessment processes (questionnaires and online tests) and the management of their tasks (Costa, Alvelosa, \& Teixeira, 2012). It can also enrich learning by providing an automated and adaptive educational assessment (Coates, James, \& Baldwin, 2005). These platforms allow the development of new participatory strategies that are focused on students in their own learning and in the development of metacognitive strategies that strengthen their autonomy (Sanchez, Sanchez, \& Ramos, 2012). Thus, a more democratic conception of networking is created on the basis of interaction, feedback, debate and collaborative work (Costa, et al., 2012; Smith \& Xu, 2016).

One of the theories that fits the pedagogical and didactic use of LMS is the theory of activity (Hashim \& Jones, 2017), where classroom or face-to-face interaction and online support generates a techno-pedagogical convergence (Vásquez, 2017), which aims to develop increasing degrees of autonomy in students and teachers, with the latter being seen as mediators, facilitators and designers of learning situations (Salmon, 2004).

Also, through these collaborative learning environments, students develop competencies that encourage the formulation of questions, explaining and justifying opinions, articulating reasoning, developing and reflecting on knowledge gained (Hashim \& Jones, 2017) on the basis of didactic activities available in questionnaires, surveys, fora and wikis (Silva et al., 2016), where the role of teachers is fundamental in designing didactic activities as well as in evaluating specific learning processes (Alias \& Zainuddin, 2005).

Now, a series of variables will determine the significance that this LMS tool can have, and in addition to the aforementioned teacher training, another advantage is that it can be a medium full of diverse tools and materials that can be used by the students (Ndlovu \& Mostert, 2017; Sahasrabudhe \& Kanungo, 2014), which, at the same time, possesses a structure that facilitates and promotes the quality of the interaction (Luo, Murray, \& Crompton, 2017) among the participants of virtual training that will be determined by the activities and actions that teachers carry out. An aspect that will lead us to talk about third-generation e-learn- ing from our perspective is its reference to a practice of virtual training that is focused not so much on perceiving it as content storage but rather on its development from the perspective of collaboration and the joint construction of knowledge by students.

On the other hand, we must remember that a diversity of studies is showing that the incorporation of video clips in LMS training scenarios is having an impact on scenarios of high quality and is well-perceived by the students (Cabero, 2018).

Faced with all these advantages, however, Moodle is still used as a repository for materials and information (Costa et al., 2012), and the development of its pedagogical use is still limited (Parson 2017; Rienties, Giesbers, Lygo-Baker, Ma, \& Rees, 2014; Rodríguez, Restrepo, \& Aranzazu, 2014).

In this sense, several authors indicate the role of beliefs and attitudes that teachers have regarding technology as determining its degree of use, both from the technological and the pedagogical perspectives (Admiraal et al., 2017; Arancibia, Halal, \& Romero, 2017). This use will be determined by the degree of acceptance of LMS technology, which will be influenced by the diversity of tools that it contains and the diversity of tasks carried out by teachers (Schoonenboom, 2014).

It has also been demonstrated that the use of technology does not ensure the transformation of pedagogical practices, as the practice is a reflection of teachers' beliefs (Tondeur, Hermans, van Braak, \& Valcke, 2008; Valverde, Garrido, \& Sosa, 2010).

In this way, the use of Moodle in the context of teaching and learning depends critically on teachers having knowledge of the tools, their being aware of how they should be used and their being able to organise the entire communication process. Instructors become a key cog as they are responsible for creating content, planning didactic activities and adopting different technological tools (Gramp, 2013). In addition, they will have the didactic and technological training that determines the strategies that can be implemented in virtual classrooms, as well as technological tools focused on systemic, interactive and communicative processes that are typical of teaching and learning (Zamora, 2018).

In the context of education, this means that students' acceptance of technology depends to a large extent on teachers (Sherbib, Mahmud, Abu Bakar, \& Mohd Ayub, 2012). In turn, the use of technology in the learning environment is more likely to increase when teachers' pedagogical approach to teaching is consistent with the selected technology (Sherbib et al., 2012). This way, teachers' beliefs, being a critical indicator for the use of technology in the classroom, tend to influence the technological integration practices (Tondeur, Hermans, Braak, \& Valcke, 2008). In other words, LMS's success in any institution begins with teacher acceptance, which, in turn, initiates and promotes student use of LMS (Al-Busaidi \& Al-Shihi, 2010).

There are also other factors associated with the pedagogical use of these platforms related to the technological environment, organisational support, technical support and training. Technological factors include system quality, information quality and the service quality (Al-Busaidi \& Al-Shihi, 2010; Alias \& Zainuddin, 2005), which constitute primary barriers, which are less critical than the beliefs and attitudes that effectively determine the use and acceptance of technology (Ertmert Ottenbreit-Leftwich, Sadik, \& Sendurur, 2012). In the role of teacher training, it has been proven in studies that the adoption of these platforms was below indicated expectations as teachers could have been poorly trained and equipped with the appropriate technological and pedagogical skills (Jenkins et al., 2010; Rienties \& Townsend, 2012). 
One element that we have pointed out, e-activities, is one of the most relevant in achieving quality training activities with the Moodle LMS (Cabero \& Román, 2006; Cabero et al., 2014; Luo et al., 2017; Silva, 2017), which, in turn, becomes a bridge element that facilitates interaction between teaching and learning. As Silva notes (2017, p. 7): 'Learning centred on activities places students at the centre of the educational process, gives them a leading role, and favours collaborative and autonomous learning'.

Finally, it indicates what several authors have already advised regarding ICT integration: the importance of actions for educational purposes and not putting tools before educational needs. Likewise, the experience of successful practices in this integration is strongly related to the careful selection of tools based on previously defined needs. In other words, what transforms education is not the incorporation of ICT in teaching processes but how it is used, something that is reflected in its application for successful scenarios with the Moodle platform.

\section{METHOD}

The research objectives were as follows:

- To explore the didactic use of classes with support from the Moodle platform;

- To review the pragmatic functionality of the platform at the repository level for tasks and activities;

- To identify whether teaching strategies are strengthened by focusing on collaboration, interaction and student autonomy.

\subsection{Population and research sample}

From a total of 4,874 teachers at the Technological University of Chile, INACAP, from all over Chile, we decided to apply the questionnaire to 640 teachers, a sample that would assure a sampling error of $3 \%$ and a confidence level of $95 \%$.

The percentage of female teachers was $36.09 \%(f=231)$ and that of male teachers was $63.91 \%(\mathrm{f}=409)$. Of these, 565 $(82.12 \%)$ worked face-to-face; $16(2.52 \%)$ online and $14(2.21 \%)$ worked face-to-face and online. The remaining percentage was distributed with low percentages in other categories (blended and online).

The participating teachers belonged to all the teaching subjects that were taught at the university (Figure 1).

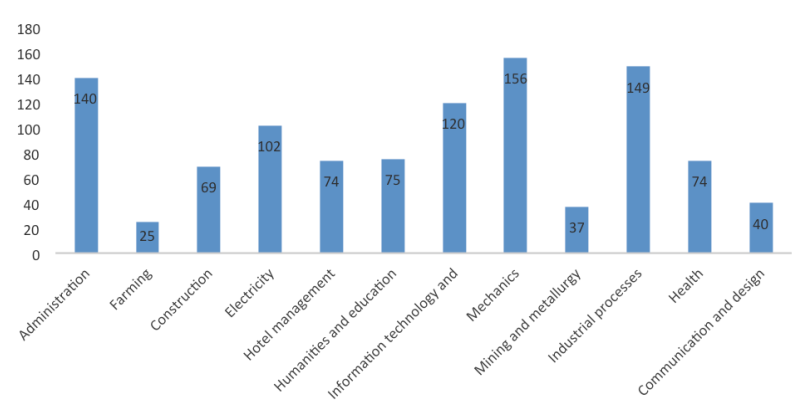

Figure 1. Teachers participating by field

\subsection{Type of study}

The study conducted is non-experimental, quantitative, ex post-facto, transversal and correlational (Arnal, Del Rincón, \& Latorre, 1992; Bisquerra, 2004), which has the advantage of simplicity but also a disadvantage, which the researchers must accept, in that it does not allow the formal establishment of coincidence
(Rosado, 2006). This aspect can be solved by 'the depth and rationality of the theoretical approaches that guide the research design' (Mateo, 2004, p. 213).

\subsection{Instruments for collecting information, procedures and reliability}

The questionnaire administered consisted of 21 items. This questionnaire sought to first identify demographic characteristics of the respondents and then to ask about different aspects of using the Moodle platform, such as technical mastery, didactic knowledge and frequency of use of Moodle; activities and strategies that are developed by the teacher using the platform; learning resources that are incorporated into Moodle and related questions about coursework using Moodle.

The survey was applied personally by the team of researchers during the second semester of 2017 and the first semester of 2018. To obtain a higher response rate, links were considered with different academic units and each campus, which helped to improve distribution, and in many cases, the application of the survey directly.

We obtained the reliability index using Cronbach's alpha, obtaining a total result of 0.91 , which means that the questionnaire is highly reliable.

In Table 1, the alpha values reached are presented.

Table 1. Cronbach's alpha for reliability of the instrument

\begin{tabular}{ll}
\hline \multicolumn{1}{c}{ Item } & Cronbach's Alfa \\
\hline Technical knowledge & 0,918 \\
Didactic management knowledge & 0,915 \\
Activity and strategies developed & 0,925 \\
using AAI & \\
Learning resources incorporated in & 0,868 \\
AAI & 0,927 \\
Coursework using AAI &
\end{tabular}

\section{RESULTS}

With regard to the mean scores and standard deviations reached in a general way for technical knowledge and didactic management of the platform, and offering an answer on a scale from 1 (very little) to 10 (a lot), the following results were obtained for technical knowledge and didactic management, with means of 6.31 and 5.76 and standard deviations of 2.61 and 2.53 , respectively. The data obtained allows us to point out two aspects: that the assessments were slightly higher than the central value of 5 , that there have been high standard deviations indicating a high dispersion in teachers' answers and that the teachers consider themselves to have greater technical knowledge of the platform than didactic management.

On the other hand, teachers' assessments of different tools on the platform with respect to their technical knowledge and didactic management that constituted the mean scores and standard deviations obtained are presented in Table 2.

As we can see, we found a series of significant findings: a) in all cases, the assessment on technical knowledge is greater than knowledge of didactic management; b) the mean scores are not very high; if we take away the strong value of email, currently a very common tool, the overall means would be 5.49 for technical knowledge and 4.88 for knowledge of didactic management; and 
c) use of the platform as a purely administrative instrument for students to deliver and collect tasks stands out.

On the other hand, the resemblance between the highest and lowest self-assessments in technical knowledge and didactic management is striking. Thus, three areas stand out with the highest scores - videos (YouTube, Vimeo, etc.), homework (delivery of files for grading or feedback) and email—and with the lowest self-assessment in videoconference/audioconference.

Table 2. Means and standard deviations of technical knowledge and didactic management

\begin{tabular}{|c|c|c|c|c|}
\hline \multirow{2}{*}{$\begin{array}{c}\text { Management of different } \\
\text { tools }\end{array}$} & \multicolumn{2}{|c|}{$\begin{array}{l}\text { Technical } \\
\text { knowledge }\end{array}$} & \multicolumn{2}{|c|}{$\begin{array}{c}\text { Didactic } \\
\text { management }\end{array}$} \\
\hline & Mean & SD & Mean & SD \\
\hline \multirow{2}{*}{$\begin{array}{c}\text { Management of different } \\
\text { tools }\end{array}$} & \multicolumn{2}{|c|}{$\begin{array}{l}\text { Technical } \\
\text { knowledge }\end{array}$} & \multicolumn{2}{|c|}{$\begin{array}{c}\text { Didactic } \\
\text { management }\end{array}$} \\
\hline & Mean & SD & Mean & SD \\
\hline Email & 9,26 & 1,46 & 8,27 & 2,36 \\
\hline Forums & 6,4 & 3,45 & 5,68 & 3,34 \\
\hline Blogs & 4,65 & 3,54 & 4,06 & 3,3 \\
\hline Wikis & 4,62 & 3,5 & 4,1 & 3,32 \\
\hline $\begin{array}{l}\text { Homework (delivery of files } \\
\text { for grading or feedback) }\end{array}$ & 7,64 & 3,05 & 7,36 & 3,11 \\
\hline Glossaries & 5,29 & 3,59 & 4,55 & 3,43 \\
\hline $\begin{array}{l}\text { Videos (YouTube, Vimeo, } \\
\text { etc.) }\end{array}$ & 6,9 & 3,41 & 6,4 & 3,4 \\
\hline Online Questionnaires & 4,44 & 3,58 & 3,9 & 3,33 \\
\hline $\begin{array}{l}\text { Co-evaluations (you evaluate } \\
\text { your classmates and they } \\
\text { evaluate you) }\end{array}$ & 5,12 & 3,75 & 4,75 & 3,64 \\
\hline Queries or surveys & 4,58 & 3,58 & 4,27 & 3,49 \\
\hline
\end{tabular}

Teachers were asked about the frequency with which they used different activities and strategies through Moodle, initially indicating that the mean value of all the activities that were indicated in the questionnaire was 5.20 and the standard deviation was 2.40 . This fact leads us to indicate the lack of strong use of the platform to carry out activities on the one hand and the great dispersion found among the scores offered by teachers on the other.

Regarding the mean scores and standard deviations obtained for each of the activities that were offered, Table 3 shows the mean values and the standard deviations obtained.

The data obtained allows us to indicate a series of aspects, some already mentioned: the strong variability of teachers' answers; the existence of a strong group of activities, with close to $40 \%$ not exceeding the intermediate value of the scale (5); the underscoring of 'Use assessment rubrics', 'Perform collaborative work activities' and 'Provide feedback on students' academic work' actions and finally its low level of use to 'Give out prizes, scores, rankings (Gamification Methodology)', 'Use Simulations (use of online simulators)' and 'Use tools for students to debate'.

With regard to how they used different learning resources that the virtual training platform incorporated, the mean score for all of them was 6.06 and the standard deviation was 2.34. With regard to mean scores and standard deviations obtained for the use of different resources, Table 4 presents the values obtained.
Table 3. Activities and strategies supported by AAI

\begin{tabular}{lcc}
\hline $\begin{array}{l}\text { Activities and strategies developed through the } \\
\text { platform }\end{array}$ & Mean & SD \\
\hline Provide feedback on students' academic work & 6,21 & 3,14 \\
Perform collaborative work activities & 6,35 & 3,23 \\
$\begin{array}{l}\text { Pose and propose problems (for example: Lear- } \\
\text { ning-Based Problem Methodology) }\end{array}$ & 5,98 & 3,29 \\
$\begin{array}{l}\text { Work with projects (for example: Project-Based } \\
\text { Learning Methodology) }\end{array}$ & 5,55 & 3,35 \\
Work with the case study methodology & 5,45 & 3,4 \\
Monitor the development of student activities & 5,62 & 3,29 \\
Conduct debates or discussion forums & 3,78 & 3,03 \\
Use simulations (use of online simulators) & 3,06 & 2,95 \\
$\begin{array}{l}\text { Give out prizes, scores, rankings (Gamification } \\
\text { Methodology) }\end{array}$ & 2,63 & 2,66 \\
Use assessment rubrics & 6,69 & 3,29 \\
Develop research & 4,28 & 3,42 \\
Promote reflection in students through different & 3,93 & 3,15 \\
tools (wikis, forums, etc.) & 3,66 & 3,15 \\
$\begin{array}{l}\text { Use tools for students to discuss } \\
\text { Allow students to analyze a case study }\end{array}$ & 5,45 & 3,46 \\
Allow students to write essays & 4,2 & 3,36 \\
\hline
\end{tabular}

Table 4. Learning resources incorporated in AAI

\begin{tabular}{lll}
\hline \multicolumn{1}{c}{ Different learning resources in AAI } & Mean & SD \\
\hline Study guides & 8,1 & 3,87 \\
Workshop or laboratory guides & 7,78 & 3,03 \\
Notes & 8,41 & 2,59 \\
Conceptual maps & 4,46 & 3,38 \\
PowerPoint or similar presentations & 8,35 & 2,68 \\
Videos & 5,47 & 3,35 \\
Audio files & 3,02 & 3,09 \\
Animations, photographs, drawings & 4,51 & 3,67 \\
Interactive multimedia material & 4,12 & 3,56 \\
Objects in augmented reality & 2,12 & 2,48 \\
Self-assessment exercises & 3,71 & 3,32 \\
Online exams & 3,06 & 3,18 \\
Access to simulators and/or virtual laboratories & 2,88 & 3,01 \\
Reading articles (PDF journal articles) & 6,39 & 3,51 \\
Ebooks & 5,25 & 3,59 \\
Manuals & 6,13 & 3,48 \\
\hline
\end{tabular}

First, it is the dimension in which the highest standard deviations were found, which indicates a wide dispersion found among teachers' responses. Second, it highlights a large group of tools used-'Study guides', 'Workshop or laboratory guides', 'Notes' and 'PowerPoint or similar presentations' - and another large 
group of unused tools - 'Objects in augmented reality', 'Self-assessment exercises', 'Online exams', 'Access to simulators and/ or virtual laboratories' and 'Audio files'.

Finally, with regard to the coursework they did using the institution's Moodle, the mean score obtained for all activities offered was 4.17 with a standard deviation of 0.89 . In this case, and for correct interpretation, it should be considered that the response options went from none (1) to a lot (6). The mean scores obtained in each of the options are presented in Table 5.

Table 5. Your coursework using AAI

\begin{tabular}{|c|c|c|}
\hline Work done with the AAI & Mean & SD \\
\hline $\begin{array}{l}\text { The teaching strategies that I employ as a tea- } \\
\text { cher using AAI made it possible to achieve the } \\
\text { training objectives of the course syllabus }\end{array}$ & 4,46 & 1,08 \\
\hline $\begin{array}{l}\text { As a teacher, I promote teaching strategies using } \\
\text { AAI }\end{array}$ & 4,22 & 1,2 \\
\hline $\begin{array}{l}\text { It is important as a teacher to encourage colla- } \\
\text { borative work through various resources (for } \\
\text { example, forums and wikis) provided by AAI }\end{array}$ & 4,32 & 1,18 \\
\hline $\begin{array}{l}\text { There is a common space for dialogue and de- } \\
\text { velopment of social ties among members in the } \\
\text { course AAI (forums, blogs, wikis, ...) }\end{array}$ & 3,64 & 1,28 \\
\hline $\begin{array}{l}\text { As a teacher, I promote student participation } \\
\text { through AAI }\end{array}$ & 4,34 & 1,25 \\
\hline $\begin{array}{l}\text { As a teacher, it is important to develop activities } \\
\text { that promote learning in AAI }\end{array}$ & 4,64 & 1,12 \\
\hline Students research and reflection using AAI tools & 3,57 & 1,3 \\
\hline $\begin{array}{l}\text { Activities were carried out in the AAI that } \\
\text { promote communicative interaction among } \\
\text { students, such as discussion forums }\end{array}$ & 3,23 & 1,42 \\
\hline $\begin{array}{l}\text { AAI has facilitated communication with } \\
\text { students }\end{array}$ & 4,37 & 1,3 \\
\hline $\begin{array}{l}\text { The technical function of the AAI is easy to } \\
\text { understand }\end{array}$ & 4,34 & 1,18 \\
\hline $\begin{array}{l}\text { The AAI platform has been easy for me to } \\
\text { navigate }\end{array}$ & 4,39 & 1,15 \\
\hline $\begin{array}{l}\text { The aesthetic quality of the environment (size, } \\
\text { typeface, colors, etc.) is attractive }\end{array}$ & 4,21 & 1,28 \\
\hline $\begin{array}{l}\text { I am generally satisfied with the pedagogical } \\
\text { usefulness of the AAI }\end{array}$ & 4,42 & 1,11 \\
\hline
\end{tabular}

In this case, the first thing to be pointed out is that the mean values obtained in all cases exceed the scale's central value of ' 3 ', with the following excelling as activities used most with Moodle: 'As a teacher it is important to develop activities that promote learning in Moodle', 'The teaching strategies that I use as a teacher with Moodle support made it possible to achieve the course's training objectives' and 'The Moodle platform is easy to browse through'.

Once the descriptive analyses have been presented, we analyse the possible relationships between the variables. To this end, we will begin by analysing the relationships between teachers' self-reported knowledge of Moodle and the technical knowledge and didactic management of different tools located in the environment mentioned in the foregoing, applying the Pearson correlation coefficient. The correlation coefficient allows us to obtain independence between two variables and the intensity of this relationship (Domenech, 1977). The overall results are presented in Table 6 .
Table 6. Global results of technical and didactic knowledge of the Moodle platform

\begin{tabular}{cc}
\hline Item & Pearson correlation \\
\hline Technical knowledge & $0,448^{* *}$ \\
Didactic management & $0,449^{* *}$ \\
\hline
\end{tabular}

Note: $* *=$ correlation significant to $\mathrm{p} \leq 0.01$

According to Mateo (2004), correlations would be moderate when placed in the interval between 0.41 and 0.70 . On the other hand, the values obtained clearly indicate that the perception that teachers have of their knowledge of Moodle has a positive and significant impact on their technical knowledge and didactic management of the platform's different tools and vice versa, with correlations that are significant at the level of significance $\mathrm{p} \leq$ 0.01. On the other hand, its positive nature indicates that both variables go in the same direction and that when one increases, the other does also.

After carrying out this general analysis, we show the correlations between the technical and didactic knowledge and the use of different platform tools. The results are presented in Table 7.

Table 7. Correlation between the technical and didactic knowledge and the use of different Moodle platform tools

\begin{tabular}{lcc}
\hline \multirow{2}{*}{\multicolumn{1}{c}{ Item }} & \multicolumn{2}{c}{ Correlations } \\
\cline { 2 - 3 } & $\begin{array}{c}\text { Technical } \\
\text { management }\end{array}$ & Didactic \\
\hline Emails &, $312^{* *}$ &, $242^{* *}$ \\
Forums &, $450^{* *}$ &, $415^{* *}$ \\
Blogs &, $421^{* *}$ &, $401^{* *}$ \\
Wikis &, $443^{* *}$ &, $406^{* *}$ \\
$\begin{array}{l}\text { Homework (file deliveries for } \\
\text { grading or feedback) }\end{array}$ &, $505^{* *}$ &, $478^{* *}$ \\
Glossaries &, $420^{* *}$ &, $392^{* *}$ \\
Videos (YouTube, Vimeo, etc.) &, $381^{* *}$ &, $352^{* *}$ \\
$\begin{array}{l}\text { Video/Audio meetings } \\
\text { Online questionnaires }\end{array}$ &, $415^{* *}$ &, $401^{* *}$ \\
$\begin{array}{l}\text { Co-evaluations (You evalua- } \\
\text { te your classmates and they } \\
\text { evaluate you) }\end{array}$ &, $477^{* *}$ &, $448^{* *}$ \\
Queries or surveys &, $436^{* *}$ &, $413^{* *}$ \\
\hline
\end{tabular}

Note: $* *=$ correlation significant to $\mathrm{p} \leq 0.01$

The correlations, according to Mateo (2004), would be between moderate ( 0.41 to 0.70$)$ and low ( 0.21 to 0.40$)$ levels. At the same time, it is noted that the values achieved for the two major knowledge areas and for all the tools presented indicate with complete clarity that teachers' self-perception regarding their general knowledge of Moodle has a significant influence on their technical knowledge and on didactic management that incorporates different tools from the environment. Note that again all correlations were positive and significant at $\mathrm{p} \leq 0.01$.

With respect to the possible relationships between the self-assessment of the technological knowledge and the activities for which they used Moodle, and again applying the Pearson correla- 
tion coefficient, the value found at the global level was 0.415 , significant at $\mathrm{p} \leq 0.01$.

With regard to the assessment of each of the 'Activities and strategies developed with Moodle support' and its possible relationship with Moodle knowledge, in Table 7, the correlations

Table 8. Correlation between activities and teaching strategies with the support of the Moodle platform

\begin{tabular}{lc}
\hline \multicolumn{1}{c}{ Item } & Correlation \\
\hline Provide feedback on students' academic work &, $330^{* *}$ \\
Perform collaborative work activities &, $386^{* *}$ \\
$\begin{array}{l}\text { Pose and propose problems (for example: Lear- } \\
\text { ning-Based Problem Methodology) }\end{array}$ &, $371^{* *}$ \\
$\begin{array}{l}\text { Work with projects (for example: Project-Based } \\
\text { Learning Methodology) }\end{array}$ &, $387^{* *}$ \\
$\begin{array}{l}\text { Work with the case study methodology } \\
\text { Monitor the development of student activities }\end{array}$ &, $368^{* *}$ \\
$\begin{array}{l}\text { Conduct debates or discussion forums } \\
\text { Use simulations (use of online simulators) }\end{array}$ &, $325^{* *}$ \\
$\begin{array}{l}\text { Give out prizes, scores, rankings (Gamification } \\
\text { Methodology) }\end{array}$ &, $240^{* *}$ \\
$\begin{array}{l}\text { Use evaluation rubrics } \\
\text { Develop research }\end{array}$ &, $319^{* * *}$ \\
\hline $\begin{array}{l}\text { Promote reflection in students through different } \\
\text { tools (wikis, forums, etc.) }\end{array}$ &, $320^{* *}$ \\
\hline Use tools for students to discuss &, $366^{* *}$ \\
Allow students to analyze a case study &, $375^{* *}$ \\
Allow students to write essays &, $418^{* *}$ \\
\hline
\end{tabular}

Note: $* *=$ correlation significant to $\mathrm{p} \leq 0.01$

Table 9. Correlation between general knowledge and learning sources

\begin{tabular}{lc}
\hline \multicolumn{1}{c}{ Item } & Correlation \\
\hline Study guides &, $230^{* *}$ \\
Workshop or laboratory guides &, $255^{* *}$ \\
Notes &, $235^{* *}$ \\
Conceptual maps &, $298^{* *}$ \\
PowerPoint or similar presentations &, $332^{* *}$ \\
Videos &, $283^{* *}$ \\
Audio files &, $195^{* *}$ \\
Animations, photographs, drawings &, $272^{* *}$ \\
Interactive multimedia material &, $322^{* *}$ \\
Objects in augmented reality &, $228^{* *}$ \\
Self-assessment exercises &, $331^{* *}$ \\
Online exams &, $316^{* *}$ \\
Access to simulators and/or virtual laboratories &, $271^{* *}$ \\
Reading articles (PDF journal articles) &, $309^{* *}$ \\
Ebooks &, $361^{* *}$ \\
Manuals &, $350^{* *}$ \\
\hline Note: **= correlation significant to $\mathrm{p} \leq 0.01$ &
\end{tabular}

Note: $* *=$ correlation significant to $\mathrm{p} \leq 0.01$ obtained are presented. Correlations have also been in line with previous findings, that is, positive, moderately high correlations, with all significant at the level of $\mathrm{p} \leq 0.01$.

With regard to the relationships between the knowledge indicated by teachers and their possible relationship with different learning resources incorporated into Moodle, mobilised by it in their teaching, the correlation using the Pearson correlation coefficient obtained for the overall assessment was 0.329 , with it being significant at $\mathrm{p} \leq 0.01$.

Delving into the particular relationships, the coefficients found are presented in Table 8, which again move in the direction of those noted above: moderate, positive and significant correlations at $\mathrm{p} \leq 0.01$.

Our last analysis focuses on the possible relationships between the variable of general Moodle knowledge and the type of work that teachers establish with the platform. The overall correlation reached was 0.515 , also significant at the level of $p \leq 0.01$.

In Table 10, we present the correlations obtained, in this case for the different activities that were noted in the questionnaire.

Correlations are between low and moderate and have all been shown to be positive and significant.

\section{DISCUSSION AND CONCLUSIONS}

The results of this research support the contention that it is not sufficient to incorporate content into the Moodle platform but

Table 10. Correlation between general knowledge and the activities supported with the Moodle platform

\begin{tabular}{|c|c|}
\hline Item & Correlation \\
\hline $\begin{array}{l}\text { The teaching strategies that I employ as a teacher } \\
\text { using AAI made it possible to achieve the training } \\
\text { objectives of the course syllabus }\end{array}$ &, $446^{* *}$ \\
\hline $\begin{array}{l}\text { As a teacher, I promote teaching strategies with the } \\
\text { support of the AAI }\end{array}$ &, $511 * *$ \\
\hline $\begin{array}{l}\text { It is important as a teacher to encourage collaborative } \\
\text { work through various resources (forums, wiki for } \\
\text { example) provided by the AAI }\end{array}$ &, $280^{* *}$ \\
\hline $\begin{array}{l}\text { There is a common space for dialogue and develop- } \\
\text { ment of social ties among members in the course AAI } \\
\text { (forums, blogs, wikis, ...) }\end{array}$ &, $329^{* *}$ \\
\hline $\begin{array}{l}\text { As a teacher, I promote student participation through } \\
\text { AAI }\end{array}$ &, $488 * *$ \\
\hline $\begin{array}{l}\text { As a teacher, it is important to develop activities that } \\
\text { promote learning in AAI }\end{array}$ &, $354 * *$ \\
\hline Students research and reflect using AAI tools &, $355^{* *}$ \\
\hline $\begin{array}{l}\text { Activities were carried out in the AAI that promote } \\
\text { communicative interaction among students, such as } \\
\text { discussion forums }\end{array}$ &, $351 * *$ \\
\hline AAI has facilitated communication with students &, $336 * *$ \\
\hline $\begin{array}{l}\text { The technical function of the AAI is easy to unders- } \\
\text { tand }\end{array}$ &, $390 * *$ \\
\hline The AAI platform has been easy for me to navigate &, $463 * *$ \\
\hline $\begin{array}{l}\text { The aesthetic quality of the environment (size, typefa- } \\
\text { ce, colors, etc.) is attractive }\end{array}$ &, $209 * *$ \\
\hline $\begin{array}{l}\text { In general, I am satisfied with the pedagogical useful- } \\
\text { ness of the AAI }\end{array}$ &, $423 * *$ \\
\hline Coursework using AAI &, $515 * *$ \\
\hline
\end{tabular}

Note: $* *=$ correlation significant to $p \leq 0.01$ 
that, at the same time, other parallel measures should be taken referring to organisational, methodological and training aspects (Alharbi \& Drew, 2014; Kang \& Shin, 2015; Mohammadi, 2015; Tarhini, Hone, \& Liu, 2014).

For all the advantages of the Moodle learning environment for the development of active and flexible learning, the results of this research work coincide with those of other studies in that its use remains mainly administrative for the delivery and collection of student homework; in other words, it is mainly used as a repository for materials and information (Costa et al., 2012). Therefore, its pedagogical use is still limited (Browne et al., 2006; Jenkins, Browne, Walker, \& Hewitt, 2010; Parson, 2017; Rienties, Giesbers, Lygo-Baker, Ma, \& Rees, 2014; Rienties et al., 2012).

For this platform to contribute to collaboration and participation, also implied is an active role played by teachers in designing and applying collaborative activities under diverse didactic approaches and also a reflexive and critical view of its practice (Fernández, Fernández, \& Gutiérrez, 2014). At the same time, students are expected to develop reflection and the ability to work collaboratively and act independently (Cebrián de La Serna, Serrano Angulo, \& Ruiz Torres, 2014).

As we observe in the results of the study, there is low use of the activities and strategies developed through the platform that support collaborative work, feedback, debate of discussion and reflection. The need to work with teachers in training is inferred from these results to strengthen pedagogical and technological knowledge (Koehler \& Mishra, 2008). On the other hand, it is important to rethink the dominant teaching approach, which is content-centred. The challenge is to move to a student-centred teaching focus (Silva et al., 2016), which implies changes in teacher practices and the creation of challenges for training centres with regard to their implementation and teacher training (Fainholc, Nervi, Romero, \& Halal, 2013).

The faculty at the university researched presents a more technical rather than didactic use of the Moodle platform; however, this technical use is still limited as it is mainly related to the mechanical function of the platform, that is, using it as a repository and to follow up on activities carried out by their students, which are results that coincide with those of studies indicating that in many cases this integration is formal and limited to the use of the virtual space as a repository of content (Pérez-Berenguer \& García-Molina, 2016).

We can then state that there are very few uses of the social, communicative and collaborative potential offered by the Moodle platform, as well as the tools and resources (Fariña, González, \& Area, 2013). The results of this research work show low didactic knowledge of the Moodle platform, which leads us to affirm that the educational practices of the teachers studied are based mainly on content transmission of information, that is, on a behavioural approach focused on the content, which is transmissible without encouraging or ensuring students' active role regarding their learning. Similar results show that the tools most used by teachers are email and homework and that the most used learning resources were concentrated in study guides, notes and PowerPoint presentations. We suppose that teachers' pedagogical approaches are based on traditional and transmissible teaching methods, which enhance student passivity and teacher knowledge - a line of research that can be explored in other studies from a qualitative perspective.

To achieve real changes in the integration of technology in the classroom, it is necessary to rethink teaching approaches that are focused on the teacher and direct them towards a student-cen- tred approach. To this end, training and a change in the beliefs of training teachers is required; however, the need to conceive technological integration must be considered through the lens of openness and flexibility as each training process requires various educational actions, and therefore different technological support tools, for its implementation (Bartolomé, 2008).

Higher education institutions require clear guidelines for adoption and technological integration considering that it is a phenomenon where multiple factors intervene. A systemic approach may be needed, which assumes the complexity of the educational phenomenon and the diversity of variables that must be contemplated in the process. It is necessary to not only provide technological resources to teachers to promote ICT integration, (Ertmert et al., 2012) but also, as stated by several researchers (Lawless \& Pellegrino, 2007; Rienties \& Townsend, 2012; Stes, De Maeyer, Gijbels, \& Van Petegem, 2012), to provide adequate professional development, training and support staff for teachers to increase their awareness of the complex interaction between technology, pedagogy and cognitive content in their different disciplines.

Finally, we note that as a future line of research, a qualitative study can be developed through in-depth interviews to explore pedagogical practices using the Moodle platform, delving into teachers' decisions to use certain activities and technological tools.

\section{REFERENCES}

Admiraal, W., Louws, M., Lockhorst, D., Paas, T., Buynsters, M., Cvicko, A., Janssen, C., de Jonge, M., Nouwens, S., Post, L., Van der Ven, F., \& Kester, L. (2017). Teachers in school-based technology innovations: A typology of theirs beliefs on teaching and technology. Computers \& Education, 114, 57-6. doi:10.1016/j.compedu.2017.06.013

Al-Busaidi, K., \& Al-Shihi, H. (2010). Knowledge Management and Innovation in Advancing Economies: Analyses and Solutions. In Proceedings of the 13th International Business Information Management Association Conference, IBIMA 2009.

Alharbi, S., \& Drew, S. (2014). Using the technology acceptance model in understanding academics' behavioural intention to use learning management systems. International Journal of Advanced Computer Science and Applications, 5(1), 143-155. doi:10.14569/IJACSA.2014.050120

Alias, N. A., \& Zainuddin, A. M. (2005). Innovation for better teaching and learning: Adopting the learning management mystem. Malaysian Online Journal of Instructional Technology, 2(2), 27-40.

Arancibia, M. L., Halal, C., \& Romero, R. (2017). Valoración y barreras en la integración del e-portafolio en el proceso de práctica inicial por parte de docentes y estudiantes de Educación Superior. Píxel-Bit. Revista de Medios y Educación, (51), 151-163.

Arnal, J., Del Rincón, D., \& Latorre, A. (1992). Investigación educativa. Fundamentos y metodologías. Barcelona: Labor.

Bartolomé, A. (2008). Entornos de aprendizaje mixtos en educación superior. RIED: Revista Iberoamericana de Educación Superior, 11(1), 15-51.

Brooks, D. C., \& Pomerantz, J. (2017). ECAR Study of undergraduate students and information technology. Retrieved from https://library.educause.edu/resources/2017/10/ecar-study-of-undergraduate-students-and-information-technology-2017

Brown, S. (2008). From VLEs to learning webs: The implications of Web 2.0 for learning and teaching. Interactive Learning Environments, 18(1), 1-10. doi:10.1080/10494820802158983

Browne, T., Jenkins, M., \& Walker, R. (2006). A longitudinal perspective regarding the use of VLEs by higher education institutions in the United Kingdom. Interactive Learning Environment, 14(2), 177-192. doi:10.1080/10494820600852795

Bisquerra, R. (Coord.) (2004). Metodología de la investigación educativa. Madrid: La Muralla.

Cabero, J., Roig, R., \& Mengual, S. (2017). Conocimientos tecnológicos, pedagógicos y disciplinares de los futuros docentes según el modelo TPACK. Digital Education, 32, 73-84.

Cabero, J., \& Román, P. (2006). E-actividades. Un referente básico para la formación en Internet. Sevilla: Eduforma.

Cabero, J. (Cood.) (2018). La incorporación de las producciones polimedias a la formación universitaria. Sevilla: SAV de la Universidad de Sevilla. 
Cabero, J., \& Marín, V. (2014). Miradas sobre la formación del profesorado en tecnologías de información y comunicación (TIC).Enl@ce: Revista Venezolana de Información de, Tecnología y Conocimiento, 11(2), 11-24.

Cabero, J, González, N., Clara, A., Ramírez, L., William, T., \& Fernández, W. (2014). Manual para el desarrollo de la formación virtual - Intec libro de estilo. Santo Domingo: INTEC.

Cebrián, M., Serrano, J., \& Ruiz, M. (2014). Las eRúbricas en la evaluación cooperativa del aprendizaje en la Universidad. Comunicar XXI, 43(22), 153-161.

Cejas, R., Navío, A., \& Barroso, J. (2016). Las competencias del profesorado universitario desde el modelo TPACK (conocimiento tecnológico y pedagógico del contenido). Píxel-Bit. Revista de Medios y Educación, 49, 105-119. doi:10.12795/pixelbit.2016.i49.07

Coates, H., James, R., \& Baldwin, G. (2005). A critical examination of the effects of learning management Systems on university teaching and learning tertiary education and management. Tertiary Education and Management, 11, 19-36. doi: $10.1080 / 13583883.2005 .9967137$

Coicaud, S. (2016). Planteos y replanteos acerca de la Tecnología Educativa como campo de conocimiento y de formación. Espacios en Blanco. Revista de Educación, 26, 81-104. Retrieved from http://www.scielo.org.ar/pdf/eb/v26n1/ v26n1a05.pdf

Costa C., Alvelosa H., \& Teixeira, L. (2012). The use of Moodle e-learning platform: a study in a Portuguese University. Procedia Technology, 5, 334-343. doi:10.1016/j.protcy.2012.09.037

Domenech, J. (1977). Bioestadística. Métodos estadísticos para investigadores. Barcelona: Herder.

Ertmert, P., Ottenbreit-Leftwich, A., Sadik, O., Sendurur, E., \& Sendurur, P. (2012). Teachers beliefs and technology integration practices: A critical relationship. Computers and Education, 59, 423-435. doi:10.1016/j.compedu.2012.02.001

Fainholc, B., Nervi, H., Romero, R., \& Halal, C. (2013). La formación del profesorado y el uso pedagógico de las TIC. RED, Revista de Educación a Distancia, 38. Retrieved from http://www.um.es/ead/red/38/fainholc.pdf

Fariña, E., González, C. S., \& Area, M. (2013). ¿Qué uso hacen de las aulas virtuales los docentes universitarios? RED, Revista de Educación a Distancia, 35

Fernández, L., Fernández, E., \& Gutiérrez, P. (2014). La colaboración docente como base para la innovación y la investigación en los entornos de aprendizaje con TIC Universidad de Extremadura, España. REDU. Revista de Docencia Universitaria, 12(4), 303-322. doi:10.4995/redu.2014.5625

Gillani, B. B. (2000). Using the Web to Create Student Centred Curriculum. In R. A. Cole (Ed.), Issues in Web Based Pedagogy. London: Greenwood Press.

Gramp, J. (2013, October). Beyond the baseline: working with e-learning champions to transform e-learning at a research-led university. In 2nd Moodle Research Conference (MRC2013). Sousse, Tunisia.

Hashim, N., \& Jones, M, (2017) Activity theory: A framework for qualitative analysis. Retrieved from http://ro.uow.edu.au/commpapers/408

Horvat, A., Dobrota, M., Krsmanovic, M., \& Cudanov, M. (2015). Student perception of Moodle learning management system: a satisfaction and significance. Interactive Learning Environments, 23, 4, 515-527. doi:10.1080/10494820. 2013.788033

Inzunza, B., Rocha, R., Márquez, C., \& Duk, M. (2014). Asignatura virtual como herramienta de apoyo en la enseñanza universitaria de ciencias básicas: implementación y satisfacción de los estudiantes. Formación Universitaria, 5(4), 3-14. doi:10.4067/S0718-50062012000400002

Jenaro, C., Martín, M. E., Castaño, R., \& Flores, N. (2018). Rendimiento académico en educación superior y su asociación con la participación activa en la plataforma Moodle. Estudios sobre Educación, 34, 177-198. doi:10.15581/004.34.177198 Retrieved from https://www.unav.edu/publicaciones/revistas/index.php/ estudios-sobre-educacion/article/view/8365

Jenkins, M., Browne, T.,Walker, R., \& Hewitt, R. (2010). The development of technology enhanced learning: Findings from a 2008 survey of UK higher education institutions. Interactive Learning Environments, 19(5), 447-465. doi:10.1080/10494820903484429

Kang, M., \& Shin, W. S. (2015). An empirical investigation of student acceptance of synchronous e-Learning in an online university. Journal of Educational Computing Research, 52(4), 475-495. doi:10.1177/0735633115571921

Kerimbayev, N., Kultan, J. Abdykarimova, S., \& Akramova, A. (2017). LMS Moodle: Distance international education in cooperation of higher education institutions of different countries. Educ Inf Technol, 22, 2125-2139. doi:10.1007/ s10639-016-9534-5

Kinchin, I. M. (2012). Avoiding technology-enhanced non-learning. British Journal of Educational Technology, 43(2), E43-E48. doi:10.1111/j.14678535.2011.01264.x

Koehler, M., \& Mishra, P. (2008). Introducing TPCK. Handbook of technological pedagogical content knowledge TPCK for educators. In Annual Meeting of the American Educational Research Association: NewYork City. Retrieved from http://punya.educ.msu.edu/presentations/AERA2008/MishraKoehler AERA2008.pdf.

Lawless, K. A., \& Pellegrino, J. W. (2007). Professional development in integrating technology into teaching and learning: Knowns, unknowns, and ways to pursue better questions and answers. Review of Educational Research, 77(4), 575-614. doi:10.3102/0034654307309921

Luo, T., Murray, A., \& Crompton, H. (2017). Designing authentic learning activities to train pre-service teachers about teaching Online. International Review of Research in Open and Distributed Learning, 18(7), 141-157. doi:10.19173/irrodl.v18i7.3037

Marciniak, R., \& Gairín, J. (2017). Un modelo para la autoevaluación de la calidad de programas de educación universitaria virtual. RED. Revista de Educación a Distancia, 54(2). doi:10.6018/red/54/2

Martínez, K., \& Torres, L. (2017). Estrategias que ayudan al docente universitario a conocer, apropiar e implementar las TIC en el aula. Píxel-Bit. Revista de Medios y Educación, 50, 159-175.

Mateo, J. (2004). La investigación ex post-facto. En R. Bisquerra (Coord.), Metodología de la investigación educativa (pp. 195-230). Madrid: La Muralla.

Mohammadi, H. (2015). Investigating users' perspectives on e-learning: An integration of TAM and IS success model. Computers in Human Behavior, 45, 359374. doi:10.1016/j.chb.2014.07.044

Ndlovu, M., \& Mostert, I. (2017). Teacher perceptions of Moodle and throughput in a blended learning programme for in-service secondary school mathematics teachers. Africa Education Review, 15, 2, 131-151. doi:10.1080/18146627.2 016.1241667

Parsons, A. (2017). Accessibility and use of VLEs by students in further education. Research in Post-Compulsory Education, 22(2), 271-288. doi:10.1080/ 13596748.2017.1314684

Pérez, E., Herrera, L., Maldonado, G., \& Mendoza, N. (2008), Aplicación de un LMS como herramienta de b-learning en estudios de posgrado. En I. Lozano \& F. Pastor (Coords.), VI Jornades d'Investigació en Docencia Universitaria: la construcció col-legiada del model docent universitari del segle. Alicante: Universidad de Alicante. Retrieved from http://rua.ua.es/dspace/ handle/10045/19962?mode=full

Pérez-Berenguer, D., \& Molina, J. G. (2016). Un enfoque para la creación de contenido online interactivo. Revista de Educación a Distancia, (51). doi:10.6018/red/51/3

Rienties, B., \& Townsend, D. (2012). Integrating ICT in business education: Using TPACK to reflect on two course redesigns. In P. Van den Bossche, W. H. Gijselaers, \& R. G. Milter (Eds.), Learning at the crossroads of theory and practice (pp. 141-156). Dordrecht: Springer. doi:10.1007/978-94-007-2846-2_10

Rienties, B., Giesbers B, Lygo-Baker S., Serena, H., \& Rees, R. (2014). Why some teachers easily learn to use a new virtual learning environment: a technology acceptance perspective. Interactive Learning Environments, 24(3), 539-552. doi:10.1080/10494820.2014.881394

Rodríguez, E., Restrepo, L., \& Aránzazu, D. (2014). Alfabetización informática y uso de sistemas de gestión del aprendizaje (LMS) en la docencia universitaria. Revista de Educación Superior, 43(171), 139-159. doi:10.1016/j. resu.2015.03.004

Rosado, M. A. (2006). Metodología de investigación y evaluación. Sevilla: Eduforma-Trillas.

Sahasrabudhe, V., \& Kanungo, S. (2014). Appropriate media choice for e-learning effectiveness: Role of learning domain and learning style. Computers \& Education, 76, 237-249. doi:10.1016/j.compedu.2014.04.006

Salmon, G. (2004). E-actividades. Factor clave para una formación en línea activa. Barcelona: Editorial UOC.

Sánchez J., Sánchez P., \& Ramos F. (2012). Usos pedagógicos de Moodle en la docencia universitaria desde la perspectiva de los estudiantes. Revista Iberoamericana de Educación, 60(60), 15-38.

Schoonenboom, J. (2014). Using an adapted, task-level technology acceptance model to explain why instructors in higher education intend to use some learning management system tools more than others. Computers \& Education, 71, 247256. doi:10.1016/j.compedu.2013.09.016

Sherbib M., Mahmud, R., Abu Bakar, K., \& Mohd, A. (2012). Factors influencing the use of learning management system in Saudi Arabian Higher Education: A theoretical framework. Higher Education Studies, 2(2).

Silva, J. (2017). Un modelo pedagógico virtual centrado en las E-actividades. RED. Revista de Educación a Distancia, 53, 10, 1-20, Retrieved from http://www. um.es/ead/red/silva.pdf.

Silva, J., Fernández, E., \& Astudillo A. (2014). Modelo interactivo en red para el aprendizaje: Hacia un proceso de aprendizaje online centrado en el estudiante. Revista Pixel-Bit. Revista de Medios y Educación, 49, 225-238.

Silva, M., García, T., Guzmán, T., \& Chaparro, R. (2016). Estudio de herramientas Moodle para desarrollar habilidades del siglo XXI. Campus Virtuales, 5(2), 58-69. Retrieved from http://uajournals.com/ojs/index.php/campusvirtuales/ article/view/126/131

Smith, Sh., \& Xu, D. (2016). How do online course design features influence student performance? Computers \& Education, 95, 270-284. doi:10.1016/j.compedu.2016.01.014

Stes, A., De Maeyer, S., Gijbels, D., \& Van Petegem, P. (2012). Instructional development for teachers in higher education: effects on students' learning outcomes. Teaching in Higher Education, 17(3), 295-308. doi:10.1080/1356251 7.2011.611872 
Tarhini, A., Hone, K., \& Liu, X. (2014). Measuring the moderating effect of gender and age on e-learning acceptance in England: A structural equation modeling approach for an extended technology acceptance model. Journal of Educational Computing Research, 51(2), 163-184. doi:10.2190/EC.51.2.b

Tondeur, J., Hermans, R., Braak, J. V., \& Valcke, M. (2008). The impact of primary school teachers' educational beliefs on the classroom use of computers. Computers \& Education, 51, 1499-1509. doi:10.1016/j.compedu.2008.02.001

Valverde, J., Garrido, M. D. C., \& Sosa, M. J. (2010). Políticas educativas para la integración de las TIC en Extremadura y sus efectos sobre la innovación didáctica y el proceso enseñanza-aprendizaje: la percepción del profesorado. Revista de Educación, 352, 99-124.

Vásquez, M. (2017). Aplicación de modelo pedagógico blended learning en educación superior. Revista DIM, año 14, 35.

Zamora, E. G. (2018). El grado de incidencia y nivel de impacto del manejo de los recursos didácticos por parte de los docentes y estudiantes dentro del aula virtual: una aproximación empírica. 3C TIC: Cuadernos de desarrollo aplicados a las TIC, 7(1), 33-46. doi:10.17993/3ctic.2018.59.33-46

How to cite this article: Cabero-Almenara, J., Arancibia, M. L., \& Del Prete, A. (2019). Technical and Didactic Knowledge of the Moodle LMS in Higher Education. Beyond Functional Use. Journal of New Approaches in Educational Research, 8(1), PP. 25-33. doi:10.7821/ naer.2019.1.327 